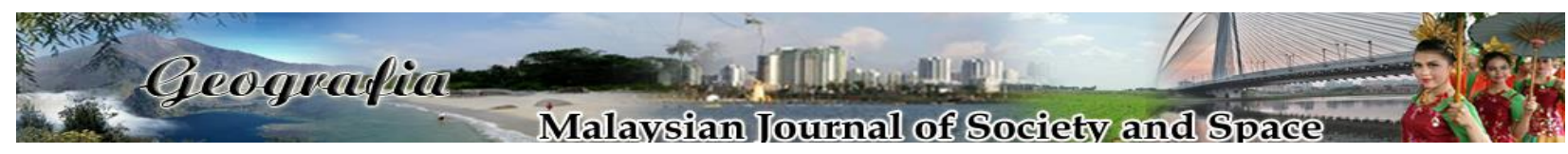

\title{
Implementing governance and regulation in Indonesia's broadcasting industry
}

\author{
Badrul Redzuan Abu Hassan ${ }^{1}$, Dewi Anggrayni ${ }^{2}$, Roslina Abdul Latif ${ }^{3}$, Putri Wahyuni ${ }^{4}$ \\ ${ }^{1}$ Centre for Communication and Digital Society, Faculty of Social Sciences and Humanities, \\ Universiti Kebangsaan Malaysia \\ ${ }^{2}$ Faculty of Economics and Communication, BINUS University, Jakarta, Indonesia \\ ${ }^{3}$ School of Communication, Taylor's University, Lakeside Campus \\ ${ }^{4}$ Department of Communication, Syiah Kuala University, Banda Aceh, Indonesia \\ Correspondence: Badrul Redzuan Abu Hassan (email: brah@ukm.edu.my)
}

Received: 08 December 2018; Accepted: 19 February 2019; Publish: 22 February 2019

\begin{abstract}
An effective mechanism of governance and regulation is crucial to the well-being of a country's media system. The idea of the State regulating the broadcasting industry does seem contradictory to economic liberalism and so surely, the State is wary that the industry operates in a free market economy for governance and regulation has its own repercussions. We situate our inquiry in the post-Reformation euphoria for media democratization in Indonesia, which historically, has established a strong relationship between oligarchic business interests and their political ambitions. Using focus group discussion as the primary method of elicitation, our research paper aims to understand deeper the strategic communicative process including meeting, planning, consultation and negotiation, and other implicit challenges involved in media governance and regulation process. We found that whilst the due process of governance and regulation remain real problem-solving events, they carry symbolic importance. There is still much improvement to be made in implementing regulatory framework including removing the ones that do not benefit the regulators. Our study implicates ethics and autonomy as two of the most outstanding issues in effective media co-regulation currently confronting the State and its regulating authorities in the face of ever-imposing media market deregulation on the broadcast industry. At the core of it all, the practice of media governance and regulation is essentially a series of 'communicative event' between the authorities, the State and the market.
\end{abstract}

Keywords: autonomy, broadcasting industry, Dewan Pers, Komisi Penyiaran Indonesia, governance, media regulation 


\section{Introduction}

This study focuses on the governance and regulation of the Indonesian broadcasting industry. It appears today that the State-owned TVRI and RRI have lost their functions as the nation's 'official voice'; overlooked by the public/ stakeholders; trapped by institutional issues like interdepartmental coordination and commitment; the flaring ethos of corruption and collusion (Nugroho et al., 2012). In post-Reformation context, there is perhaps an 'absence' of a transparent State media policy to govern and regulate the profit-driven logic of the industry's elite capitalists. The ever-growing media privatization due to market forces, symptomatic media monopoly and oligopoly and gradual liberalisation of the public sector and weakening of the public sphere (for example, public may get more channels but less content options). Hence, our paper asks a basic question: 'how does the State apprehend and cope against such phenomenon'?

\section{Literature review}

The deregulation of State media systems that eventually results in the concentration of media ownership in the hands of powerful businessmen-cum-neoliberal politicians should not be entirely seen as a mark of democracy of the free markets. McChesney (2001) has argued that media deregulations stemmed from "unthinkable improvements in [information and] communication technology" as well as "the incessant pursuit for profit [through] the relaxation or elimination of barriers to commercial exploitation of media and to concentrated media ownership" which may potentially affect freedom of expression. He believes that because wealthy private owners will "dominate the journalism and media in a society", this monopoly will create problems of governance and regulation for the State. Studies however, have shown that the global responses to the governance and regulation discourse have been far from singular or monotonous.

Allen (2013) shows in his study that coloured ethnic minority groups in the United States who used to enjoy $34 \%$ of control of broadcast media content, now have limited opportunities to voice their communal interest following the impact of State-sponsored merger of media ownership. Conversely, the deregulations of media laws have brought greater access to ethnic minority communities in India, as pointed out by Satpathi and Roy (2011), who may now have access to non-stop news from 33 channels especially on political debates during election seasons when the media industry habitually deregulates itself during general elections to promote political programs. The deregulation sentiment is apparently shared by Gaber (2018) whose recent study on political journalism suggests that the over-reliance and over-compensation of public trust on the British Broadcasting Corporation (BBC) reflects 'journalistic failure' for there are many 'truths', not only the 'BBC truths' per se, which raised questions on the re-regulations of public broadcasting on political journalism.

\section{Broadcasting laws}

According to Wahyuni (2016), many conglomerates try to influence the policy outcome and legislation by influencing the lawmakers in the Indonesian House of Representatives. Since the fall of the New Order in 1998 following the Reformasi (reformation) movement, the Indonesian media laws have gone through several stages of post-Reformation evolution. Amendments were 
made to the Indonesian Constitutional Laws (Undang-Undang Dasar, UUD) 1945 and Human Rights Law No. 39/1999. These were landmark decisions for the people of Indonesia because these State laws apparently guaranteed every Indonesian the freedom to information and access to the media. Since the ascendency of President Soeharto in 1963 until his resignation in 1998, the Indonesian broadcast media has evolved through 35 years of centralised power and administrative control known the 'New Order' or 'Orde Baru', where the central government in Jakarta would keep a close watch over broadcast media stakeholders against unethical if politically-motivated content and programs. Subsequent laws that were passed indicate that the State would not allow anarchical sentiments to override its hard-fought struggle for freedom of speech and social democracy.

There is perhaps a possible 'exception to the rules' in this country, in the case of the Aceh Province where apparently, the implementation of the sharia laws or qanun (a preferred terminology in the context of Aceh's Islamic laws) apparently has superceded the State's broadcasting governance and regulation by making it the de jure and de facto broadcasting practices in the province (Syamsul Bahri, 2012). It is rather important to understand the implication of the Islamic or sharia laws on a provincial broadcasting system and the nature of media governance and co-regulation that it extends to this autonomous Indonesian province (Alyasa, 2006). The Aceh autonomous government has deployed one section of the Constitutional Law No.11/2006 to provide the province's KPI (therefore KPID) with the authority to draft media content and broadcast program which are deemed sharia compliant for the consumption of Acehnese households. This proposed broadcasting program was tabled in the Aceh's House of Commons (Dewan Perwakilan Rakyat Aceh) to be validated and legislated as bill. The programme's rationale indicated that the Aceh KPID has clearly that recognized its media governance and regulatory role is solely to help sustain the province's autonomy and safeguard the practice and sanctity of the sharia law for the Aceh people.

\section{Key stakeholders in the broadcasting industry}

According to Sudibyo and Nezar (2013), given the television's unique characteristics, Indonesian businessmen-cum-politicians always know that it is vital to own and exert control over TV stations. There are 3 major broadcasting conglomerates dominating the Indonesian media systems under the purview of Dewan Pers and Komisi Penyiaran Indonesia, namely, MetroTV (2001), GlobalTV (2002) and TVOne (2008). Briefly, MetroTV is recognized as the first digital channel catering the Indonesian household needs for a hundred percent news TV; GlobalTV offers entertainment variety whereas TVOne profiles a 70-30 percent news-sportainment ratio to attract commanding urbane viewership. Perhaps more interestingly, it is a well-known fact that these broadcast stations are owned by Indonesian politicians: MetroTV's Surya Paloh is the leader of Parti Nasional Demokrat (Nasdem) based in Aceh; GlobalTV's Hary Tanoesoedibjo supports Parti Hanura whereas TVOne's Aburizal Bakrie used to helm Parti Golkar during the Suharto era.

The legacy of 'paternalistic government-business relationship' (Zainuddin, 2010) is well known in Asian societies particularly in East Asian states and it originally refers to the traditionally good relationship between the government and its society as a whole. To cite an example, according to Kim (2011:170), the regulation paradigm of Korean broadcasting industry changed with democratization of politics in the 1990s where hitherto, "the purpose of broadcasting regulation regime was for protection and restriction" from foreign cultural 
influence. The meaning of this cosy relationship takes a drastic turn when a clear differentiation between business and politics becomes fuzzy. The ever presence of businessmen-cumpoliticians, hence a potential media-politics collusion breeding inside the local mass mediasphere have turned them and both regulating bodies to public scrutiny from media to election watchdogs to social scientists.

Media conglomerates have been known to deploy their broadcasting stations to campaign for their parties but also, not surprisingly, for themselves too. In fact, the recent General Elections / Presidential Elections (Pilpres) 2014 media campaigns reflected the State's failure to regulate the Broadcasting Law No. 32/2002 from media practitioners' perspective. Public media and election watch groups engaged themselves in co-regulating a mediasphere that was no longer independent and neutral. The media ownership-politics collusion during the Pilpres unfolded into proxy battle between two broadcast stations: TVOne (known to be pro-Prabowo Subianto/Hatta Rajasa faction) versus MetroTV (known to be a pro-Joko Widodo/Jusuf Kalla faction). Historically, unethical relationship involving business and political interests in the Indonesian media came into public domain in the Sidoarjo mud flow tragedy whereby PT Lapindo, which in this case is the defender, had sought TVOne to engineer public consent in order to protect its political and economic interests (Nugroho, 2012).

\section{Method}

The data collection technique for the purpose of this study is in-depth interview involving two sets of active members of Dewan Pers and KPI. A total of 6 informants were selected to represent 3 broad professional categories of membership: journalism, media or academia. The informants were identified alphabetically as Informants A (Head of Dewan Pers), B (Legal Department, Dewan Pers), C (Corporate Department, Dewan Pers), D (Corporate Department, KPI), E (Legal Department, KPI) and F (Corporate Department, KPI). The instrument of data collection used involved a set of 6 semi-structured interview questions and a voice recorder to store audio files before they were transcribed in verbatim before translated from Indonesian into English. Two sessions of focus group interviews were conducted for both sets of Informant in Bahasa Indonesia by our Indonesian Graduate Research Assistant. In order to understand how a 'communicative event' is experienced on daily basis by the regulators, we deployed the following semi-structured discussion questions on two focus groups comprising Dewan Pers and KPI officials:

a) How would you define self-governance and regulation of the media for the broadcasting industry?

b) What procedures are used by Dewan Pers or KPI in regulating media content in broadcasting programmes?

c) Is there a formal set of rules to be adhered to by regulating bodies and the broadcast media industry?

d) Would there be an informal set of rules used by regulating bodies and the broadcast media industry?

e) How frequent does Dewan Pers or KPI have their meetings and what would be the typical issues raised by its members in these meetings? Are they considered formal or informal meetings? 
f) How would you understand the concept of 'freedom of expression'? What is the limit of such freedom and how could such limitation give an impact on the practices of the broadcasting industry?

\section{Findings}

\section{Scope of regulative discourse}

It was learnt from the interviews that the history of regulative discourse in Indonesia's media system began in earnest when the Ministry of Information tabled Press Law No. 40/1999. This post-Reformation law brought in significant changes to Indonesian journalism as it apparently gives considerable press freedom such as narrowing the scope of media gate-keeping as well as giving more licences for private media operators. By implication, these changes have equally important implications for the broadcasting industry too. This is because both public and private broadcast media bear the responsibility to disseminate members of the public with information which they received from journalists. The reform particularly to Indonesian journalism's code of ethics was thoroughly and successfully exploited by media organizations in the land, a phenomenon which was dubbed as, according to Informant A, the 'new order journalism'. According to this Informant, despite a somewhat erratic trajectory of growth throughout the years, the new freedom has seen media organizations in Indonesia mushroomed from 270 print and electronic media and 20 radio stations to almost 1500 media outlets not including electronic media.

Along with the changing mediascape came the necessary structural reform for the purpose of better governance and regulation. According to Informant B, the responsibility for overseeing the practices of media outlets was handed over by the Ministry of Information to Dewan Pers. He was quick to add that under the New Order, the role of Dewan Pers was merely accessory and advisory to the State under full authority of the Minister of Information. In contrast, reflecting the spirit of democracy and transparency, the elected members of this regulating body today is made up from journalists, academics and social critics or activists - that is, those who not only want the State to continue to endorse new and existing regulations that will sustain the function of Dewan Pers; but they also want to ensure that members of the public will be able to voice out their media-related concerns directly to the State, as it were.

\section{Standard operating procedures}

As generally agreed by our Informants, the regulating bodies, either Dewan Pers or KPI will only act upon receipt of formal complaint from members of the public claiming that there has been a violation against the ethics of journalism. Upon investigation by the proper section members of the authority, and wherein the claim of such a case cannot be proven, the complainant has a right of reply which is copied to Dewan Pers. Dewan Pers will look at this issue and determine its importance since at times a complaint may not have anything to do with journalism. If there is a case to be made, Dewan Pers will then write to the media organization for an official explanation. If the complainant is not satisfied, he or she is reserved the right to make an inquiry or respond in writing to seek further appropriate action. 
According to Informant F, there will be several meetings with the Ministry of Information at various stages that may include case evaluation, hearing of opinions and screening conditions, to name but a few, before the Ministry can make an informed and authoritative decision on procedural matters. However, interestingly, although Informant D thinks that the procedure is apparently consistent with Broadcasting Law No 32, 1999, in practice, broadcast media regulators are still surrounded by teething procedural issues related to the autonomy, privileges and ethical practices that Dewan Pers and KPI regulators can and cannot have. Informant F made a concise point that despite the amendments to the relevant media laws, the KPI's role remains strictly regulatory in nature. He further suggested that since the regulating body cannot 'touch' on media content, the existing framework of broadcasting laws must be reviewed and revamped. Informant $\mathrm{E}$ brought this point to the next level by arguing that the consultative yet domineering position of the Ministry in the entire procedure could itself be construed as a potential 'violation' of their rights and independence.

It is apparent that the issue of jurisdiction as much as ethics have been bothering the efficiency of State regulating bodies who are answerable to the people more than any other social institution. Informant $\mathrm{E}$ appeared to be intolerant to the lack of a clear and visible chain of command that was indicative of the broadcast content regulation procedure in the New Order era. The post-Reformation press freedom has probably seen more and more public protests which were not as rampant as during the New Order because, as Informant B argued, all information came from the government. Informant B cited the gag by the New Order government banning media coverage of an Indonesian royal family before the broadcast media is regulated and governed via code of ethics.

The independence of both regulating bodies continues to be in doubt because of State intervention in the process of electing their executive members. As informed by Informant $\mathrm{C}$, the appointment of Dewan Pers's membership for the 2006-2009 term delayed for quite a while pending the President's Decree or Keppres (Keputusan Presiden) which eventually was signed by former President Susilo Bambang Yudhoyono in February 2007. This effectively placed the entire operationalization of Dewan Pers under duress. The new board membership consisting of 9 representatives of three groups (journalists, community leaders and press corporate leaders) as stipulated in article 15 of Press Law No. 40/1999 was duly fulfilled. However, according to Informant $\mathrm{C}$, the composition of these 9 people cannot be considered ideal as the elected journalists were strongly linked with policy makers in Jakarta, whereas our Informant felt that acknowledgment and solidarity should have been extended to provincial-based journalists to capture their voices and local issues on the margins.

\section{Ethics and governance}

The ethics and governance of media and journalism in Indonesia is informed by Dewan Pers's 11-chapter booklet on journalistic code of ethics that is supported by 26 journalistic and media organizations in the country. Informant B gave a holistic account of the ethical functions of Dewan Pers which range from ensuring the development of freedom of the press, improving the national press, protect press freedom from interference by other parties, conducting studies for the development of the press, establish and oversee the implementation of the journalistic codes of ethics is all important. Informant A made an important reference to Circular No. 1 of Dewan Pers, which states that any Indonesian media outfit should establish itself either as a private company, foundation or co-operative; and it cannot be considered a legal media organization if it 
is deemed to have violated the journalistic codes of ethics. Dewan Pers should assume the role as an internal adjudicator in the event of a complaint is lodged against a media outfit. Informant $\mathrm{A}$ admitted that journalists have flouted and abused their freedom and shown little common sense or responsibility for their reporting which is detrimental to the image of Dewan Pers. As part of its mitigating practice against irresponsible journalism, Informant $\mathrm{C}$ points out that Dewan Pers conducts competency test against affiliated journalists' unions or organizations in order to determine the status, duties and functions of the journalists. If any journalists are in violation, they will be sanctioned and a revocation of their license.

As for KPI, a regulating body established with specific focus on broadcast media content, Informant F, D and E all agreed that whilst its regulations are clearly published in the KPI booklet, they need to be reviewed periodically because of the dynamism and novelties brought over by digitalisation and other related media and communication technologies. The KPI booklet interprets the press and the public broadcasting based on Broadcasting Law No. 32, 2002 and typically serves as KPI's standard reference on broadcast media regulation and guidelines known as Pedoman Perilaku Penyiaran Standar Program Siaran (P3 SPS), Informant F added that KPI has been transparent about its operationalization as part of its socializing campaign in educating the media industry about ethical practice and good media governance. In this regard, all Informants unanimously agreed that the main task of KPI and Dewan Pers's is to drive the life of the media and democratization process in Indonesia.

Here, Informant $\mathrm{C}$ quite succinctly recalled and illustrated this agenda in the context of Dewan Pers's priorities for the 2006-2009 period of regulation, which was "to develop communication between the press, the public, and the government" (Article 15, clause 2e under the Press Law No. 40/1999). According to Informant C, Dewan Pers should be able to develop an understanding of the various parties to maintain the freedom of the press. In many cases, there is often substantive (not procedures) disagreement about the issue of double standards between Dewan Pers, prosecutors, police, and even some in the media community itself. As an independent agency that is free from government pressure, Dewan Pers has the maximum opportunity to act as an independent mediator for all parties to the dispute with the media. Decisions are always to priority litigation (out of court) should still be pursued to ensure the freedom of the press and press workers away from criminalization. However, in this Informant $\mathrm{C}$ would have like to see Dewan Pers to show courage and be more vocal with the government, especially in the presence of the powerful Ministry of Communications and Information Technology, who may exert its authority and control on the function of the press just like what the Ministry of Information did during the New Order.

\section{Informal set of rules}

Majority Informants, except for Informant D, confidently believed that all standard operation procedures have been integrated and deployed with regularity within the provision of the P3 SPS and corroborates with the Press Law No. 40/1999 as well as Broadcasting Law No, 32/2002, without recourse to informal practice or approach. Dewan Pers for example, regularly meets every Friday besides its monthly plenary, although Informant B does not rule out informal meeting depending on its necessity especially on the issue played out by the media. In fact, Dewan Pers, which comprises 4 bureaus: Legal, Corporate, Education and Public Complaints Bureau, has already participated as witness to assist in the proceedings of legal cases. There are 3 
circumstances in which Dewan Pers may deploy its own informal procedures to resolve regulatory-related issues, which are:

a) If it is implicated with legal proceeding through a police report;

b) If it seen as a form of threat or intimidation to the media and public, and

c) If a complaint report has been made by a third-party.

In such matter, as Informant A explained, Dewan Pers will do its assessment and assume an adjudicative role through the legal department by summoning the enforcement or complaints officials involved for investigations. There are 2-3 meetings a week depending on the number of reports received as well as a monthly plenary to listen to various comments, evaluations and recommendations.

\section{Type of issues}

Meetings, whether formal or informal, are important mechanism to KPI and Dewan Pers to discuss governance and regulation matters. Informant B shared how meeting frequency increased during key events such as the recent general election campaigns where rampant breaching of journalistic code of ethics were reported to Dewan Pers. Also, during the Air Asia flight crash tragedy. In 2014 alone, about 800 reports had been lodged to Dewan Pers ranging from ethical violations of journalism to oppressive harassment against journalists. According to Informants D and $\mathrm{E}$, besides the annual meeting of all $34 \mathrm{KPI}$ officials at the national level, there will usually be weekly meetings and the cases to be brought up in these meetings will be handled by the regulators according to their respective bureaus or areas of specialisation. Unofficial meetings are often unscheduled and will also be called if there is a high occurrence of unethical or unlawful media violation found other than those reported. Based on Informant E's experience, in 2014 alone, a total of 190 official meetings had taken place to discuss various violations against the codes of laws and ethics. While Informant F claimed that these meetings often reflect the issues developing in the public sphere or community of practice, Informant $\mathrm{E}$ noticed that the Ministry of Information has been rather too slow to attend to and fulfil their duties in this important process.

\section{Freedom of expression}

The notion of 'freedom of expression' that pertains to journalism's community of practice is highly subjective and sensitive; and it is contested as a matter of interpretation. This is evident in the varied responses from the Informants which somewhat implicates the Indonesian broadcast media industry with a post-Reformation disillusionment about the actual meaning and interpretation of media freedom of expression. The governance and regulation of broadcast media are also apparently suffering from the lack of communication and coordination between KPI and Dewan Pers. Indonesia's freedom of expression, in the opinion of Informant A, is so overwhelming that it needs to reform its broadcasting laws. There have been continuous violations of media and journalism codes of ethics despite the claim by Informant B that the Indonesian media laws are far better than other countries in the region. Informant A repudiated such a claim for the very fact that regulating bodies have been overruling one another in cases where the suspicion of vested interest reigns high. Informant A cited a critical example when 
Dewan Pers wanted to review and reprimand the violation in election news coverage by TVOne and MetroTV sometime ago, it had to enter into an unnecessary confrontation about its overlapping jurisdiction with KPI. Informant B lamented the fallacy of so-called media independence in Indonesia because media collusion with political and business elites is making regulating bodies lose their independence. He further commented that in accordance with the vision and mission of a broadcast station, news media content cannot simply be turned away from articulating public interests. It is learnt at this point that Dewan Pers has started working towards a regulation that will limit the media ownership/relationship to not more than 5 media per politician during electoral campaign. Whilst the efforts to free the media from powerful elites continue, the 'elephant in the room', according to Informant C, is the potential criminalization of, or mildly put, restriction on press freedom under Article 18 of the Press Law itself. Media and press freedom are increasingly criminalized. For example, if the press does not provide a proper answer (to an allegation) it could be charged with a 500 million Rupiah in fines. Indonesia is a media heaven when total freedom of the press is accounted for. Informants D and E believed in curtailing media freedom since the broadcast media are exploiting it to make maximum profit without thinking of the impact when certain codes of ethics are flouted. They also lamented the laidback attitude of the Ministry of Information who, despite having the authority to mete out charges and adjudicate cases, seldom punish the media offenders after receiving feedback from KPI.

It is apparent for Informant $\mathrm{E}$ that in the final analysis, the governance and regulation of broadcasting industry must begin with the commitment between media owners and the State to uphold the code of ethics. Media owners should have a deep sense of duty and responsibility to what is being broadcasted to members of the society. Although this seems to set the limit of freedom of expression, it is also an indication of strength rather than weakness by those in the Indonesian broadcasting industry as a whole. Similar response came from Informant F who believes that the onus is always on the media practitioner to decide where and when draw the line, so to speak. Having a strong sense of responsibility is still the key to knowing whether they have gone over the limit. Sharing many of the sentiments exposed by Informant D, he regards the media freedom in Indonesia is unparalleled elsewhere including its neighbouring Malaysia. There is no censorship or gaps in accessing any information at all for either the media or the public. Informant $\mathrm{F}$ urges the Indonesian government to improve its broadcasting laws so that a media regulating body like the KPI knows its functions and commitments, and is capable of discharging its executive powers like a truly independent statutory body.

\section{Analysis and discussion}

The analysis on the findings results in the following summary:

a) All informants from Dewan Pers and KPI point towards a public education or socialisation of media governance and co-regulation in Indonesia. They want a media freedom that gives members of the public the opportunity to be actively involved with the practice of media governance and co-regulation in accordance with democratic principles. Half of the Informants claim that the process of liberating the Indonesian media is on-going and it started since the beginning of the New Order. 
b) The regulation of media content by Dewan Pers and KPI is done to achieve the goal of an ethical and independent freedom of press, of expression along the legitimacy of existing Indonesian laws on media, broadcasting and human rights. Dewan Pers and KPI are both tasked to oversee a series of progressive media laws are doing their job to protect the interests and independence of various parties in the industry.

c) There are clear officially written rules and regulations for both Dewan Pers and KPI. They are there to ensure ethical journalistic codes are being practised in the broadcast media industry which in turn will promote greater sense of media governance and regulation; and ultimately public satisfaction.

d) All informants apparently agreed that there ought to be a better informal coordination between officials, the broadcast media industry and members of the public whereby coregulatory decisions may be made through joint discussions but still along the established statutory rulings of each organization.

e) Dewan Pers and KPI clearly accommodate difference in opinions as a style of governance. They both hold special meetings depending on the case or current issues. Interestingly, they have different modes of meetings as well as frequency of meeting. The former has notched lesser meeting frequency than the latter. However, the former seems to be making up for it by holding monthly plenary meetings which the latter does not itself commit to. The formality and frequency of their meetings are dependent on the types of case or current issues.

f) Overall, majority informants think that the media should be 'free' but also be responsible. Importantly, they believe that there must be some limits on how much freedom of expression should be allowed to the Indonesian broadcast media. It is apparent that most of Dewan Pers and KPI Informants feel that now is the time to revise the media law in Indonesia again.

This summary clearly highlights two general aspects in the face of media deregulation phenomenon dominating the discourse of governance and regulation between these regulating bodies, which are, ethics and autonomy. As far as ethics is concerned, Indonesian media regulators have been business-like in discharging their responsibilities within the principles of democracy and rule of law. Their modus operandi in monitoring and regulating media policies and laws have been generally non-confrontational but co-operative. The regulators are actually professionally trained to resolve issues concerning breach of conduct and content-related violation through formal and informal discourses. It seems that they want to play active roles in building healthy media relations amongst the players, for it is not just about them playing the sentinel game, but are also cautious of either new or natural trickery and trappings within the broadcasting industry itself. They do understand that because the broadcast industry is about mass communication, journalistic activities, sharing and shaping of public opinions, there must be a clear standards and guidelines which the industry players must adhere to.

The use of social media application such as Facebook has increased the visibility and integrity of Dewan Pers and KPI in public eyes but they need to increase the level of reciprocity and hospitality from their end on such a highly interactive platform of communications. 
Transparency is a critical social capital globalised societies and it serves them long term benefit by continuing to deploy social media application to keep the public informed of the reasons their actions when it comes to the freedom of and access to information. Maintaining public presence and engagement in increasingly digitalised community is an important process of socialisation of media governance and regulation in a country that has not yet 'lost' control of the 'plot' on democratization and media freedom.

Ethics and ethos aside, a more sensitive but central issue pertains to the real power and authority to subdue and negotiate the forces and antics of media deregulation phenomenon in Indonesia. It may even be safely suggested that the governance and regulation of the Indonesian broadcasting industry is in a state of paradox. Whilst apparently independent, neither Dewan Pers nor KPI have within their jurisdictions the power to exert sanction against the infringing party. Yet, both agencies have been mandated by the government to monitor, regulate and negotiate through the complex terrains of the Indonesian broadcast media system. Indeed, as asserted by Nugroho et al. (2012), current media ownership concentration in Indonesia is posing a serious challenge particularly to the public's diminishing influence on the choice of news and infotainment against the vested interests of the powerful media conglomerates.

This preliminary study has shown an important aspect in media policy studies, that is, whilst the laws are in seeming enforced, they do not necessarily benefit the media regulating bodies. When the State is in control of the structure and financing of Dewan Pers and KPI, it seems inevitable that those designated policies and laws to safeguard the 'publicness' of broadcast media, as it were, will not be as effective as they can be. The failure to regulate the broadcast media industry is really frustrating the officials who, if it may be suggested here, are feeling cuckolded and demoralised by the State's own doing. It appears, if one may be so bold as to suggest this, but charging offenders apparently, is never always the sole prerogative of the enforcer for it may take a 'diplomatic turn' when media conglomerates-cum-politicians are involved. The collusion between self-serving media barons with political ambition and media content regulators and although corruption should never be condoned, it is a real challenge of integrity that Dewan Pers and KPI have to face.

\section{Conclusion}

In conclusion, this preliminary study has attempted to explore the process of governance and regulation in the broadcasting industry whilst the State is in control of the structure and financing of the regulating bodies, they will not be effective without good governance, (co-)regulations and strong democratic principles of freedom and transparency. This is the paradox of governance and regulation of the Indonesian broadcasting industry. It has inspired instructive comment from Indonesian scholars that the Dewan Pers and KPI regulators "despite playing a decisive role in ensuring that media civilizes the public, are not in a strong position in governing the media. The current condition hints at institutional failure, with the industry being able to overcome the regulations and the rules set by the regulators".

Several issues have sprung to mind from this study such as: Would the prospect of media governance and regulation be more positive if media owners and gatekeepers start thinking and working towards better co-regulatory initiatives more seriously with Dewan Pers and KPI for the sake of the society at large, rather than business and political interests? How would the gap between the authority-defined as well as the everyday-defined media landscape be addressed and 
manoeuvred by these regulators? It may be said at this point that there is apparently a tension between the ideology of the State and the reality confronting the regulators on a daily basis. The due process of broadcast media governance and regulation from the perspective of Dewan Pers

and KPI should be allowed to take effect in such a highly-commercialised, highly-politicised and an increasingly deregulation-prone broadcasting industry.

\section{Acknowledgement}

This study was supported by the SK-2014-014 Co-Regulation and Governance in the Indonesian Media System research grant received from the Department of Southeast Asian Studies, Passau University, Germany, under the guidance of Prof. Rudiger H. Korff.

\section{References}

Allen, J. (2013). Disappearing diversity? FCC deregulation and the effect on minority station ownership. Indiana Journal of Law and Social Equality, 2(1), 230-247.

Alyasa, A. (2006). Syari'at Islam di Provinsi Nanggroe Aceh Darussalam: Paradigma, kebijakan dan kegiatan. Banda Aceh, Dinas Syariat Islam.

Gaber, I. (2018). New challenges in the coverage of politics for UK Broadcasters and Regulators in the 'Post-Truth' environment. Journalism Practice, 12(8), 1019-1028

Kim, M. (2011). The role of the government in cultural industry: Some observations from Korea's experience. Keio Communication Review, 33, 163-182.

McChesney, R.W. (2001). Global media, neo-liberalism and imperialism. Monthly Review. 52(10), 1-19. Retrieved from http://monthlyreview.org.

Nugroho, Y., Siregar, M.F., \& Laksmi, S. (2012). Mapping media policy in Indonesia. Retrieved from https://www.escholar.manchester.ac.uk.

Satpathi, S., \& Roy, O. (2011). The impact of the electronic media on the modern Indian voter: A study of the post liberalization era. Global Media Journal (Indian Edition) Summer Issue, $1-29$.

Syamsul Bahri. (2012). Pelaksanaan syari'at Islam di Aceh sebagai bagian wilayah negara Kesatuan Republik Indonesia (NKRI). Jurnal Dinamika Hukum. 12(2), 1-12.

Sudibyo, A., \& Patria, N. (2013). The television industry in Post-Authoritarian Indonesia. Journal of Contemporary Asia. 43(2), 257-275

Wahyuni, H.I. (2016). Indonesian broadcasting policy: The limits of re-regulation to create a democratic broadcasting system. Media Asia. 33(3-4), 153-161

Zainuddin, H. (2010). New media policy: A comparative perspective on Malaysia and Korea. Jurnal Pengajian Media Malaysia. Malaysian Journal of Media Studies, 12(1), 37-52. 